\title{
Supplementation of conjugated linoleic acid in dairy cows reduces endogenous glucose production during early lactation ${ }^{1}$
}

\author{
Kristin Hötger, ${ }^{* 2}$ Harald M. Hammon, ${ }^{* 2}$ Claudia Weber, ${ }^{*}$ Solvig Görs, ${ }^{*}$ Arnulf Tröscher, $\dagger$ \\ Rupert M. Bruckmaier, $\ddagger$ and Cornelia C. Metges ${ }^{* 3}$ \\ *Department of Nutritional Physiology ‘Oskar Kellner', Leibniz Institute for Farm Animal Biology, 18196 Dummerstorf, Germany \\ †BASF SE, 67117 Limburgerhof, Germany \\ ‡Veterinary Physiology, Vetsuisse Faculty, University of Bern, 3001 Bern, Switzerland
}

\section{ABSTRACT}

Trans-10,cis-12 conjugated linoleic acid (CLA) supplementation causes milk fat depression in dairy cows, but CLA effects on glucose metabolism are not clear. The objective of the study was to investigate glucose metabolism, especially endogenous glucose production (eGP) and glucose oxidation (GOx), as well as hepatic genes involved in endogenous glucose production in Holstein cows supplemented either with $50 \mathrm{~g}$ of rumen-protected CLA (9\% trans-10,cis-12 and $10 \%$ cis-9,trans-11; CLA; $\mathrm{n}=10)$ or $50 \mathrm{~g}$ of control fat $(24 \%$ C18:2; Ctrl; $\mathrm{n}=10$ ) from wk 2 before parturition to wk 9 of lactation. Animal performance data were recorded and blood metabolites and hormones were taken weekly from 2 wk before to 12 wk after parturition. During wk 3 and 9 after parturition, glucose tolerance tests were performed and eGP and GOx were measured by [U${ }^{13} \mathrm{C}$ ] glucose infusion. Liver biopsies were taken at the same time to measure total fat and glycogen concentrations and gene expression of pyruvate carboxylase, cytosolic phosphoenolpyruvate carboxykinase, glucose6-phosphatase, and carnitine palmitoyl-transferase 1. Conjugated linoleic acid feeding reduced milk fat, but increased milk lactose output; milk yield was higher starting 5 wk after parturition in CLA-fed cows than in Ctrl-fed cows. Energy balance was more negative during CLA supplementation, and plasma concentrations of glucose were higher immediately after calving in CLAfed cows. Conjugated linoleic acid supplementation did not affect insulin release during glucose tolerance tests, but reduced eGP in wk 3, and eGP and GOx increased with time after parturition. Hepatic gene expression of cytosolic phosphoenolpyruvate carboxykinase tended to be lower in CLA-fed cows than in Ctrl-fed cows. In spite of lower eGP in CLA-fed cows, lactose out-

\footnotetext{
Received September 5, 2012.

Accepted December 10, 2012

${ }^{1}$ Part of the thesis of K. Hötger submitted to the School of Veterinary Medicine Hannover, Germany.

${ }^{2}$ Both authors contributed equally to this paper.

${ }^{3}$ Corresponding author: metges@fbn-dummerstorf.de
}

put and plasma glucose concentrations were greater in CLA-fed cows than in Ctrl-fed cows. This suggests a CLA-related glucose sparing effect most likely due to lower glucose utilization for milk fat synthesis and probably because of a more efficient whole-body energy utilization in CLA-fed cows.

Key words: conjugated linoleic acid, endogenous glucose production, transition period

\section{INTRODUCTION}

High-yielding dairy cows are not able to compensate completely for the energy lost due to milk production during early lactation by a sufficient increase of feed intake (Bell and Bauman, 1997; Drackley et al., 2001; Kokkonen et al., 2005). This leads to the mobilization of body reserves resulting in a negative energy balance that may be associated to health problems. In turn, this can negatively affect animal welfare and profitability of milk production (Bauman, 2000; Drackley et al., 2001; Eastridge, 2006). One possibility to reduce milk energy output in dairy cows is the decrease of milk fat content by feeding rumen-protected conjugated linoleic acid (CLA), in particular the trans-10, cis-12 CLA isomer (Baumgard et al., 2000; Bauman et al., 2008). Reports on CLA-induced alterations of macronutrient and energy metabolism in cows are inconsistent, and CLA effects may depend on the dietary status and the stage of lactation of the investigated cows (Bauman and Griinari, 2003; Selberg et al., 2004; CastañedaGutiérrez et al., 2005; Odens et al., 2007). Concerning glucose metabolism, CLA elevated plasma glucose concentrations in one study (Odens et al., 2007), but, in general, investigations on glucose metabolism with respect to CLA supplementation in dairy cows are limited to glucose concentrations in blood plasma and insulin responses (Bauman et al., 2008). However, it is unknown if CLA supplementation in dairy cows also changes glucose turnover.

Availability of glucose in the mammary gland is essential for high lactose production and, thus, milk production in dairy cows (Drackley et al., 2001; Brockman, 
2005) because lactose is the major osmoregulator for mammary uptake of water (Linzell, 1972; Rigout et al., 2002). In ruminants, very little glucose originates from net portal absorption, and endogenous glucose production (eGP); that is, the sum of gluconeogenesis and glycogenolysis, provides most of the glucose for milk production (Danfaer, 1994; Bell and Bauman, 1997; Brockman, 2005; Aschenbach et al., 2010). Therefore, hepatic glucose production strongly increases after calving in dairy cows to provide glucose (Danfaer, 1994; Bell and Bauman, 1997; Brockman, 2005; Aschenbach et al., 2010). However, it is not known if CLA supplementation affects eGP as well as glucose oxidation $(\mathbf{G O x})$ in high-yielding dairy cows during early lactation. As feeding trans-10,cis-12 CLA reduces milk fat synthesis, and glucose is needed for milk fat synthesis (Grummer and Carroll, 1991; Bauman and Griinari, 2003), we tested the hypothesis that CLA supplementation may decrease eGP and affect hepatic gene expression of enzymes involved in eGP and hepatic FA oxidation to explain lower glucose use due to reduced milk fat synthesis. Therefore, the objective of this study was to quantify in vivo eGP and GOx, as well as hepatic mRNA abundance of enzymes involved in gluconeogenesis and FA oxidation of CLA-supplemented dairy cows.

\section{MATERIALS AND METHODS}

\section{Animals and Feeding}

All experimental procedures were carried out according to German animal protection law and approved by the relevant authorities of the state MecklenburgVorpommern, Germany. Twenty Holstein cows with comparable milk production (first lactation $>9,000 \mathrm{~kg}$ of milk in $305 \mathrm{~d}$ ) from the research herd of the Leibniz Institute for Farm Animal Biology (FBN), Dummerstorf, or purchased from a local farm, were kept in a tie stall and were randomly allocated to 2 groups before the beginning of their second lactation.

Cows were fed ad libitum a TMR supplemented with either with $50 \mathrm{~g} / \mathrm{d}$ of Lutrell pure (BASF, Ludwigshafen, Germany) containing $9.3 \%$ trans-10,cis-12 and $10.3 \%$ cis-9,trans-11 CLA isomers (CLA; $\mathrm{n}=10$ ), or 50 $\mathrm{g} / \mathrm{d}$ of control fat (BASF; Ctrl; $\mathrm{n}=10$; Table 1). Both fat types were provided in a rumen-protected form. Conjugated linoleic acid supplementation lasted from 2 wk before estimated calving date to wk 9 of lactation (supplementation period). From wk 10 to 12 in both groups, fat supplementation was removed from the ration (depletion period); the experiment was terminated at wk 12 of lactation. Cows were investigated in 5 blocks consisting of 4 cows in each block (2 Ctrl and 2 CLA cows) from July 2009 to August 2010. Cows did
Table 1. Fatty acid composition of conjugated linoleic acid (CLA) and control (Ctrl) supplements ${ }^{1}$

\begin{tabular}{lcc}
\hline Fatty acid $(\%)$ & CLA & Ctrl \\
\hline C14:0 & 0.24 & 0.28 \\
C15:0 & $<0.1$ & $<0.1$ \\
C16:0 $16: 1$ & 11.11 & 11.55 \\
C18:0 & $<0.1$ & $<0.1$ \\
C18:1 cis-9 & 53.34 & 53.50 \\
C18:2 cis-9,cis-12 & 10.43 & 10.12 \\
C18:2 trans-10,cis-12 CLA & 0.67 & 23.52 \\
C18:2 cis-9,trans-11 CLA & 9.26 & $<0.1$ \\
C18:3 cis-9,cis-12,cis-15 & 10.30 & $<0.1$ \\
C20:0 & $<0.1$ & $<0.1$ \\
C22:0 & 0.53 & 0.55 \\
C24:0 & 0.49 & 0.47 \\
Others & $<0.1$ & $<0.1$ \\
\hline
\end{tabular}

${ }^{1}$ CLA-supplemented cows were fed ad libitum TMR (Table 2) supplemented with $50 \mathrm{~g} / \mathrm{d}$ of Lutrell pure (BASF, Ludwigshafen, Germany) from $14 \mathrm{~d}$ before calving to 63 DIM. Ctrl cows were fed ad libitum TMR (Table 2) supplemented with $50 \mathrm{~g} / \mathrm{d}$ of control fat (rumen-protected sunflower oil from BASF) from $14 \mathrm{~d}$ before calving to 63 DIM.

not suffer from clinical diseases such as metritis, milk fiber, ketosis, or displaced abomasum. When mastitis occurred, cows were treated with antibiotics and milk data during clinical mastitis were removed from data analyses.

Cows had free access to water. Individual feed intake was recorded daily. Feed samples (TMR, corn and grass silage) were pooled weekly, stored at $-20^{\circ} \mathrm{C}$ until analyzed according to Naumann and Bassler (2004) at the Agricultural Faculty of the University of Rostock and at the Landwirtschaftliche Untersuchungs- und Forschungsanstalt (LUFA, Rostock, Germany). Ingredients and chemical composition for the close-up (wk 2-0 before parturition) and lactation diet (wk 1-12 of lactation) are shown in Table 2. Cows were milked twice daily and milk samples were taken once weekly for measurement of fat, lactose, and protein in milk at the Landeskontrollverband für Leistungs- und Qualitätsprüfung Mecklenburg-Vorpommern e.V. (Güstrow, Germany). In milk samples collected in wk 3 and 9 of lactation, FA pattern was determined at the Lehrstuhl für Tierzucht, Technische Universität München (Kranzberg, Germany) as described (Sigl et al., 2010). Energycorrected milk and energy balance were calculated as described (Hammon et al., 2009). Body weight, BCS, and back fat thickness (BFT) were recorded weekly (Duske et al., 2009).

\section{Metabolites and Hormones}

Blood samples were taken by jugular venipuncture (Vacuette, Greiner Bio One International, Kremsmünster, Austria) once weekly (day relative to calving \pm 1 $\mathrm{d}$ tolerance) after the morning milking and before cows 
Table 2. Ingredients and chemical composition of $\operatorname{diets}^{1}$

\begin{tabular}{|c|c|c|}
\hline \multirow[b]{2}{*}{ Item (\% of DM) } & \multicolumn{2}{|c|}{ Diet } \\
\hline & Close-up & Lactation \\
\hline \multicolumn{3}{|l|}{ Ingredient } \\
\hline Corn silage & 36.3 & 30.7 \\
\hline Grass silage & 27.6 & 14.9 \\
\hline Straw & 10.2 & 1.9 \\
\hline Hay & - & 6 \\
\hline Concentrate MLF $2000^{2}$ & - & 33.3 \\
\hline Concentrate Universal $18 / 3^{3}$ & 16.5 & - \\
\hline Extracted rapeseed meal & 7.4 & 4 \\
\hline Dried beet pulp & - & 8.3 \\
\hline Minerals $^{4,5}$ & 2 & 0.9 \\
\hline \multicolumn{3}{|l|}{ Chemical composition $^{6}$} \\
\hline Utilizable protein & 13.2 & 16.3 \\
\hline Crude fat & 3.3 & 3.0 \\
\hline $\mathrm{ADF}$ & 18.2 & 16.3 \\
\hline NDF & 33.1 & 29.1 \\
\hline $\mathrm{NE}_{\mathrm{L}}(\mathrm{MJ} / \mathrm{kg}$ of $\mathrm{DM})$ & 6.5 & 7.2 \\
\hline
\end{tabular}

${ }^{1}$ Close-up diet was fed $14 \mathrm{~d}$ before parturition; lactation diet was fed after parturition.

${ }^{2}$ Concentrate MLF 2000 (Vollkraft Mischfutterwerke GmbH, Güstrow, Germany) consisted of (g/kg of DM) $330 \mathrm{~g}$ of soy, $200 \mathrm{~g}$ of corn, 170 $\mathrm{g}$ of wheat gluten, $130 \mathrm{~g}$ of wheat, $80 \mathrm{~g}$ of rape seed expeller, $50 \mathrm{~g}$ of low sugar beet pulp chips, calcium $(0.13 \mathrm{~mol} ; 5.2 \mathrm{~g})$, sodium $(0.42 \mathrm{~mol}$; $9.65 \mathrm{~g})$, chloride (0.03 mol; $1.2 \mathrm{~g})$.

${ }^{3}$ Concentrate Universal 18/3 (Vollkraft Mischfutterwerke GmbH) consisted of $(\mathrm{g} / \mathrm{kg}$ of DM) 200-400 g of cereals (triticale, rye, wheat, barley), <250 g of rapeseed expeller, malt germs, wheat gluten, wheat bran, peeled oat-bran, beet pulp chips, molasses, glycerin, calcium $(0.19 \mathrm{~mol} ; 7.5 \mathrm{~g})$, phosphorus (0.18 mol; $5.5 \mathrm{~g})$, sodium $(0.09 \mathrm{~mol} ; 2 \mathrm{~g})$, retinol $(9.66 \mu \mathrm{mol} ; 2.4 \mathrm{mg}), \beta$-carotene $(8.95 \mu \mathrm{mol} ; 4.8 \mathrm{mg}), 25-\mathrm{OH}-$ vitamin $\mathrm{D}_{3}(0.05 \mu \mathrm{mol} ; 22.5 \mu \mathrm{g})$.

${ }^{4}$ Mineral supplements in close-up feeding: Anionen-Mix 1141 (Salvana, Sparrieshoop, Germany), g/kg of DM: calcium (3.5 mol; $140 \mathrm{~g}$ ), sulfur $(3.9 \mathrm{~mol} ; 125 \mathrm{~g})$, chlorine $(3.4 \mathrm{~mol} ; 120 \mathrm{~g})$, magnesium (4.1 mol; 100 $\mathrm{g}$ ), phosphorus ( $0.65 \mathrm{~mol} ; 20 \mathrm{~g}$ ), retinol $(0.48 \mathrm{mmol} ; 0.12 \mathrm{~g}), \beta$-carotene $(0.45 \mathrm{mmol} ; 0.24 \mathrm{~g}), 25-\mathrm{OH}$-vitamin $\mathrm{D}_{3}(3 \mu \mathrm{mol} ; 1.25 \mathrm{mg})$, DL- $\alpha-$ tocopherolacetate $(8.5 \mathrm{mmol} ; 4 \mathrm{~g})$.

${ }^{5}$ Mineral supplements in lactation feeding: Rinderstolz 9522 (Salvana), $\mathrm{g} / \mathrm{kg}$ of DM: calcium ( $5 \mathrm{~mol} ; 200 \mathrm{~g}$ ), phosphorus (1.6 mol; $50 \mathrm{~g}$ ), magnesium $(2.5 \mathrm{~mol} ; 60 \mathrm{~g})$, sodium $(3.5 \mathrm{~mol} ; 80 \mathrm{~g})$, retinol $(1.2 \mathrm{mmol} ; 0.3$ $\mathrm{g})$, $\beta$-carotene (1.1 mmol; $0.6 \mathrm{~g}), 25$-OH-vitamin $\mathrm{D}_{3}(12 \mu \mathrm{mol} ; 5 \mathrm{mg}$ ), DL- $\alpha$-tocopherolacetate $(9.5 \mathrm{mmol} ; 4.5 \mathrm{~g})$.

${ }^{6}$ German Society of Nutrition Physiology (2001).

were allowed to eat. Tubes either contained anticoagulants dipotassium-EDTA $(1.8 \mathrm{mg} / \mathrm{mL}$ of blood $)$ and sodium fluoride (3 $\mathrm{mg} / \mathrm{mL}$ of blood) for triglycerides, NEFA, BHBA, cholesterol, glucose, and urea analyses, and potassium-EDTA $(1.8 \mathrm{mg} / \mathrm{mL}$ of blood) for insulin and glucagon analyses in blood plasma. Blood samples were kept on ice before centrifugation at $4^{\circ} \mathrm{C}$ and 1,500 $\times g$ for $20 \mathrm{~min}$. Plasma aliquots were stored at $-20^{\circ} \mathrm{C}$ until analyses.

Plasma metabolites were analyzed with an automatic analyzer (Pentra 400, Axon Lab, Reichenbach, Germany) at the clinic for cattle at the Stiftung Tierärztliche Hochschule (Hannover, Germany). Measurements of plasma concentrations of glucose and cholesterol were performed with kits from MTI Diagnostics (no. 553230, no. 553-124, Idstein, Germany). Triglycerides, urea, BHBA, and NEFA concentrations were analyzed using kits no. A11A01640, no. LT-UR 0050, no. RB 1008, and no. 434-91795 from Horiba Europe GmBH (Hannover, Germany), Lehmann (Berlin, Germany), Randox Laboratories (Crumlin, UK), and Wako Chemicals GmbH (Neuss, Germany), respectively. Plasma insulin concentrations were analyzed by RIA as described before (Hammon and Blum, 1998). Plasma glucagon concentrations were measured by RIA using a kit from Linco (GL-32K, Linco Research, St. Charles, MO; Hammon et al., 2009).

\section{Glucose Tolerance Test}

A glucose tolerance test (GTT) was performed at the beginning of wk 3 and 9 of lactation, respectively. After overnight food withdrawal, cows were fitted with jugular catheters (Cavafix Certo 338, Braun, Melsungen, Germany) for infusion of a glucose bolus $\left(1 \mathrm{~g} / \mathrm{kg}^{0.75}\right.$; Hammon et al., 2010). Blood samples for determination of plasma glucose and insulin concentrations were collected 15 and 5 min before, and 5, 10, 15, 20, 45, 60, and $120 \mathrm{~min}$ after glucose infusion in tubes containing $1.6 \mathrm{mg}$ of potassium-EDTA $/ \mathrm{mL}$ of blood (Monovette, Sarstedt AG, Nürnberg, Germany) and were put on ice until centrifuged at $1,500 \times \mathrm{g}$ for $20 \mathrm{~min}$ at $4^{\circ} \mathrm{C}$. Plasma aliquots were stored at $-20^{\circ} \mathrm{C}$ until analyzed for glucose and insulin as described above.

\section{eGP and GOx}

Three days after GTT at wk 3 and 9 of lactation, respectively, eGP and GOx were determined after overnight food withdrawal using a primed continuous intravenous infusion of $\left[\mathrm{U}_{-}{ }^{13} \mathrm{C}\right]$-glucose $\left[99\right.$ atom $\%{ }^{13} \mathrm{C}$, Eurisotop, Staint Aubin, Cedex, France; prime: 5.4 $\mu \mathrm{mol} / \mathrm{kg}$; infusion: $7.5 \mu \mathrm{mol} /(\mathrm{kg} \times \mathrm{h})]$ for $4 \mathrm{~h}$ (Hammon et al., 2008; Steinhoff-Wagner et al., 2011). Cows were fitted with 2 jugular catheters (Cavafix Certo 338) for tracer infusion and blood sampling. Blood samples were collected 10 and 5 min before tracer infusion and at $10,30,60,90,120,150,180,210$, and $240 \mathrm{~min}$ after start of infusion in tubes containing Li-heparin (14 to $15 \mathrm{IU} / \mathrm{mL}$; S-Monovette, Sarstedt, Nürnberg, Germany). Enrichment of $\left[\mathrm{U}_{-}{ }^{13} \mathrm{C}\right]$-glucose was determined by GC-MS (QP2010, coupled with GC 2010; Shimadzu, Duisburg, Germany) as recently described (Hammon et al., 2008; Steinhoff-Wagner et al., 2011). Whole blood in potassium-EDTA tubes collected before and at regular intervals between 10 to $240 \mathrm{~min}$ after start of tracer infusion was used to isolate $\mathrm{CO}_{2}$, to measure its ${ }^{13} \mathrm{C} /{ }^{12} \mathrm{C}$ 
by ratio by mass spectrometry, and to calculate GOx (Hammon et al., 2008).

\section{Analyses in Liver}

Liver biopsies were taken at the end of wk 3 and 9 of lactation, respectively, immediately frozen in liquid nitrogen, and stored at $-80^{\circ} \mathrm{C}$ until analyzed (Duske et al., 2009). Liver tissue was homogenized and glycogen concentration in liver was determined with a commercial photometric test kit based on amyloglucosidasecatalyzed release of glucose (no. 10207748035; Boehringer Mannheim/R-Biopharm, Mannheim, Germany). Measurement of liver fat concentrations was performed as described (Kuhla et al., 2004).

Transcript levels were determined for pyruvate carboxylase (PC; EC 6.4.1.1), cytosolic phosphoenolpyruvate carboxykinase (PEPCKc; EC 4.1.1.32), glucose6-phosphatase (G6Pase; EC 3.1.3.9), and carnitine palmitoyl-transferase 1 (CPT $\mathbf{1}$; EC 2.3.1.21) by the LightCycler Real-Time PCR System (Roche Applied Science, Mannheim, Germany), using SYBR Green I as detection format (Pfaffl, 2001; Hammon et al., 2009). Glyceraldehyde-3-phosphate dehydrogenase was used as a reference gene because it was not affected by diet and time. Primer sequences were recently published (Hammon et al., 2009; van Dorland et al., 2009). Melting temperatures were checked for specificity of each product. Gel electrophoresis of the PCR product demonstrated only one single band of the expected size. Products were verified by sequencing using an ABI Sequencing kit (ABI Big Dye Terminator, Applied Biosystems, Darmstadt, Germany) and an ABI 310 Genetic Analyzer (Applied Biosystems). Relative quantification of mRNA concentrations was performed as described (Pfaffl, 2001; Hammon et al., 2009). Efficiencies of PCR were $>1.8$, and inter- and intra-assay CV for reverse transcription-PCR were $<1 \%$, respectively.

\section{Statistical Analyses}

Data are presented as LSM \pm SEM. For data measured daily, such as DMI and milk yield, data were condensed to weekly means for statistical analyses. For glucose and insulin plasma concentrations during GTT, the area under the curve ( $\mathbf{A U C}$; $\mathrm{AUC}_{\text {gluc }}$ and $\mathrm{AUC}_{\text {ins }}$, respectively) was calculated using the Graph-Pad computer program (GraphPad Software Inc., San Diego, CA). Basal concentrations were subtracted to calculate net AUC. Performance, metabolic, and hormone data, as well as eGP, GOx, AUC, and liver data were analyzed by the MIXED procedure (SAS/STAT 9.2, 2009; SAS Institute Inc., Cary, NC) with diet, time of blood sampling, and diet $\times$ time interaction as fixed effects, and individual cows as random effect. Differences were localized by Tukey $t$-test. For performance, metabolic, and hormone data, data were evaluated for treatment and time effects during supplementation and depletion periods separately. Data were considered significantly different when $P<0.05$ and trends were discussed when $P \leq 0.15$.

\section{RESULTS}

\section{Animal Performance}

After parturition, DMI increased $(P<0.01)$ in both groups with time, and tended to be lower $(P=0.15)$ in CLA-fed cows than in Ctrl-fed cows (Table 3). Body weight decreased in both groups around parturition $(P$ $<0.01$ ) until wk 4 of lactation and tended to be higher before parturition (interaction $P=0.07$ ) in Ctrl-fed than in CLA-fed cows (Table 3). Back fat thickness and BCS decreased $(P<0.01)$ in both groups with onset of lactation (Table 3 ). Milk yield increased slightly more in Ctrl-fed than in CLA-fed cows, but after wk 5 of lactation milk yield was higher in CLA-fed than in Ctrlfed cows (interaction $P<0.01$; Figure 1A). Energycorrected milk showed time effects $(P<0.01)$ for both groups (Table 3). As expected, CLA supplementation reduced milk fat concentration $(P<0.01)$ and milk fat yield $(P<0.01)$ by 14 and $13 \%$, respectively (Figure $1 \mathrm{~B}$ and $\mathrm{C})$. After termination of CLA supplementation, both milk fat concentration and yield increased $(P<$ 0.01) in CLA-fed cows, and milk fat concentration - but not yield - was still lower $(P<0.05)$ in CLA-fed than Ctrl-fed cows. Milk protein concentration and protein yield peaked $(P<0.01)$ at 3 wk, whereas milk urea tended to peak $(P<0.1)$ at 4 wk of lactation and then all decreased in both groups (Table 3$)$. Lactose concentration and yield increased $(P<0.01)$ after the onset of lactation, and lactose yield was higher $(P<0.05)$ during CLA supplementation and tended to be higher $(P<0.1)$ during depletion period in CLA-fed than in Ctrl-fed cows (Table 3). Energy balance decreased $(P<$ $0.05)$ with onset of lactation, but increased $(P<0.01)$ after wk 2 of lactation until the end of the study in both groups, and was higher $(P<0.05)$ during supplementation in Ctrl- than CLA-fed cows (Table 3).

In milk fat, concentrations of most of the short- and medium-chain FA (C4:0-C16:0) were lower $(P<0.05$ or less) in CLA-fed than Ctrl-fed cows (Table 4). Stearic and oleic acid in milk fat were higher $(P<0.05)$ in CLA-fed than Ctrl-fed cows. Concentration of trans10,cis-12 CLA was higher $(P<0.05)$ in CLA-fed than Ctrl-fed cows, whereas the cis-9,trans-11 CLA isomer did not differ between groups. 
Table 3. Effect of conjugated linoleic acid (CLA) supplementation from 2 wk before parturition to wk 9 of lactation on DMI, body condition, milk performance, and energy balance of $\operatorname{cows}^{1,2,3}$

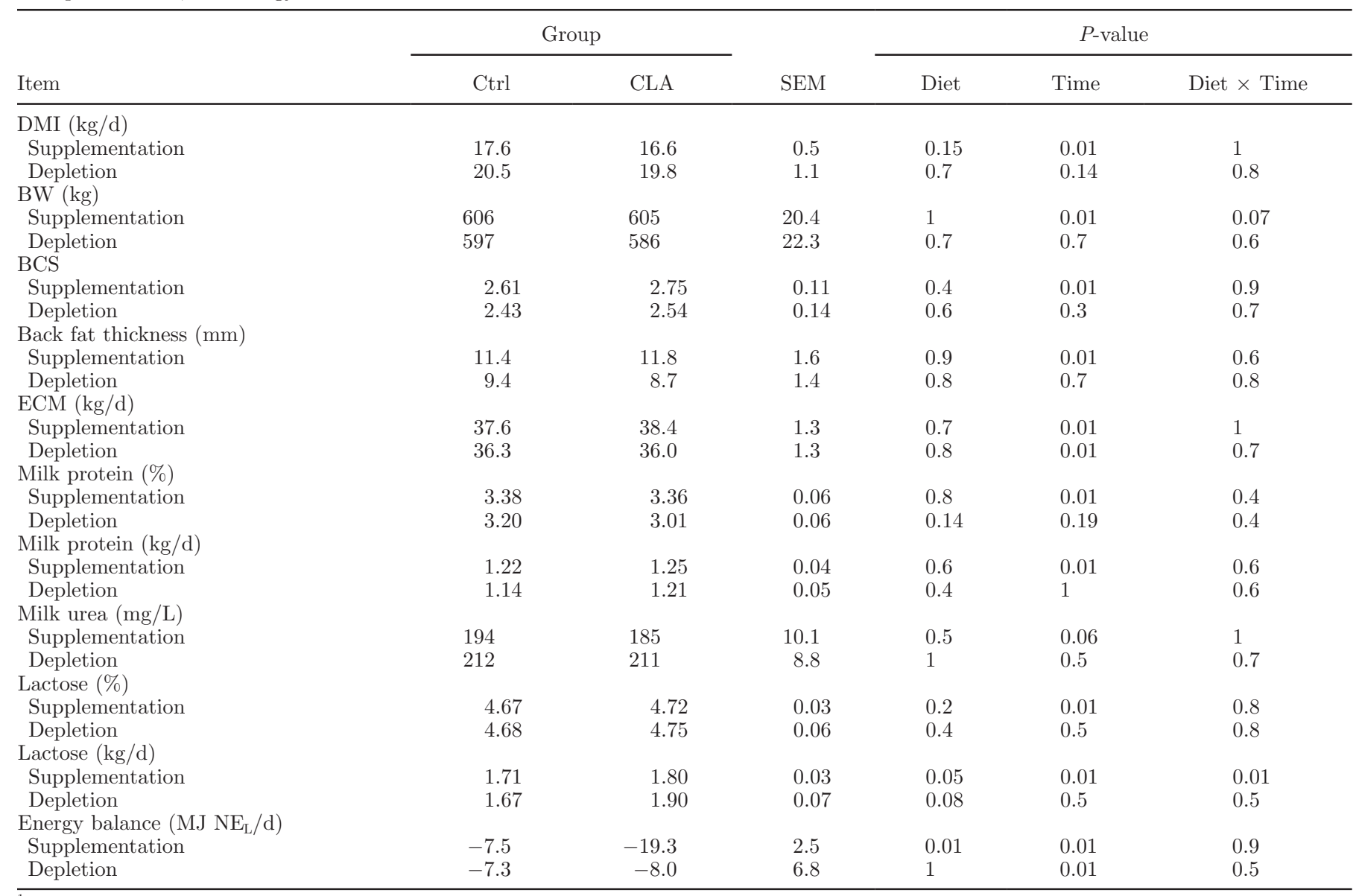

${ }^{1}$ Samples were collected in wk 3 and wk 9 of lactation from cows supplemented with CLA and control fat (Ctrl), fed from 2 wk before parturition up to wk 9 of lactation.

${ }^{2}$ Values are least squares means and pooled SEM, $\mathrm{n}=10$ per group.

${ }^{3}$ Time courses of parameters are presented as figures in a Supplementary File, available online at http://www.journalofdairyscience.org/.

\section{Metabolites and Hormones}

Cows receiving CLA showed elevated plasma concentrations of glucose (Figure 2) from wk 1 to 5 of lactation (interaction $P<0.01$ ). Plasma concentrations of NEFA, BHBA, cholesterol, glucagon, and the glucagon to insulin ratio increased $(P<0.01)$; whereas plasma concentrations of triglycerides and insulin decreased $(P<0.01)$ with onset of lactation (Table 5). Plasma concentrations of cholesterol tended to increase more steeply in CLA- than in Ctrl-fed cows (interaction: $P<0.15$; Table 5). Plasma triglyceride concentrations increased (interaction: $P<$ 0.15) during wk 10 of lactation in CLA-fed cows - after termination of CLA supplementation-but not in Ctrlfed cows. Plasma urea concentrations increased $(P<$ 0.05) from wk 4 of lactation in Ctrl-fed cows and from wk 5 in CLA-fed cows and urea concentrations tended to be lower $(P<0.15)$ during supplementation in CLA-fed than Ctrl-fed cows (Table 5).

\section{eGP, GOx, and GTT}

Endogenous glucose production and GOx increased $(P<0.01)$ with time during lactation, and in wk 3 eGP was lower $(P<0.05)$ in CLA-fed than Ctrl-fed cows (Table 6). Basal plasma glucose concentration increased from wk 3 to 9 (Table 6). Plasma glucose and insulin concentrations increased after glucose infusion during GTT in wk 3 and $9(P<0.01)$, and insulin secretion based on AUC tended to increase with time in CLA-fed cows, but not in Ctrl-fed cows (interaction; $P<0.15$; Table 6$)$.

\section{Measurements in Liver}

Total fat concentrations in liver were higher $(P<$ 0.05 ) in wk 3 than in wk 9 of lactation (Table 7). Hepatic glycogen concentrations did not differ with respect to CLA supplementation and time. Gene expression of 
A
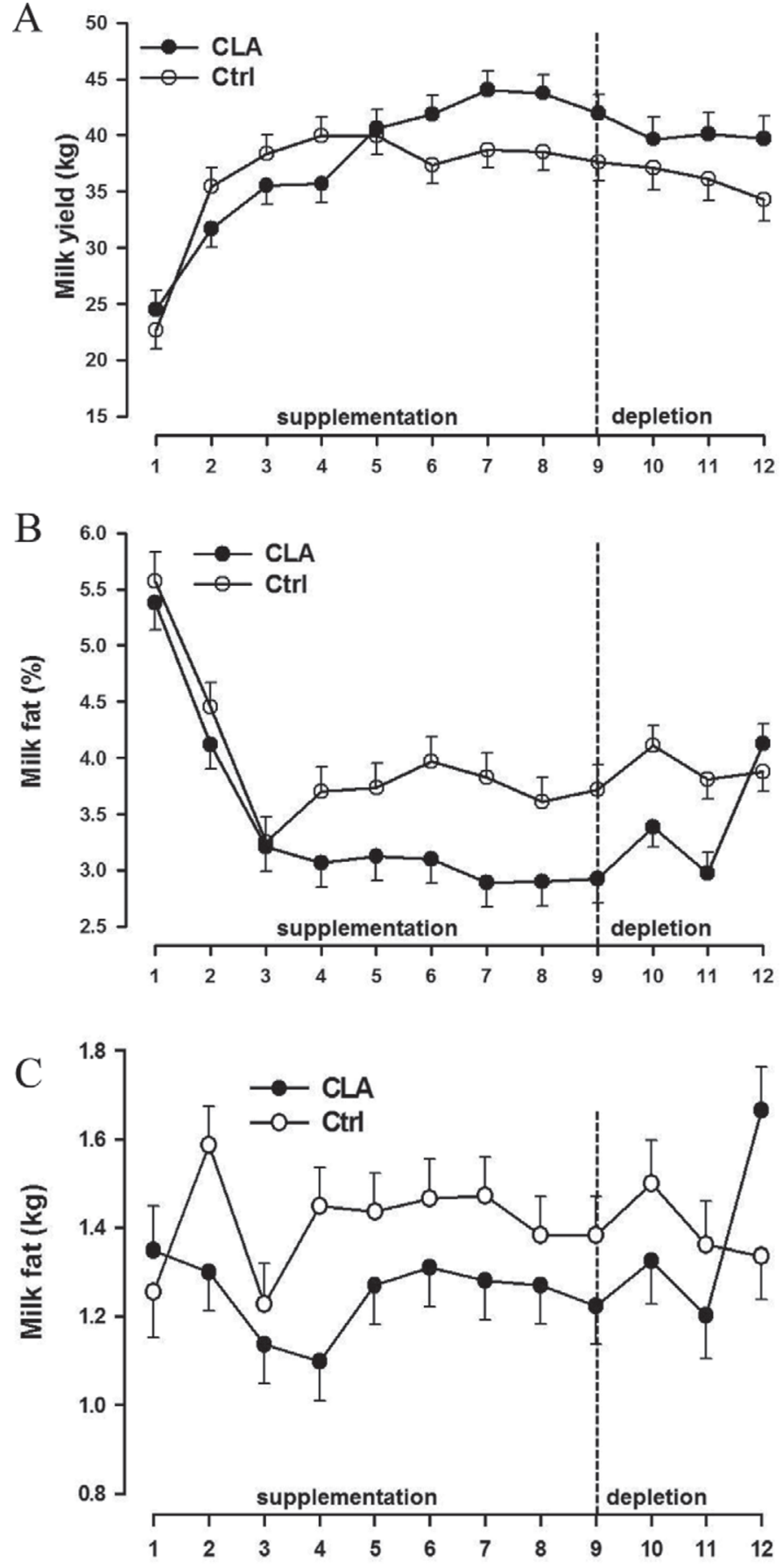

Time relative to calving (wk)

Figure 1. Milk yield (A), milk fat content (B) and fat yield (C) in dairy cows either supplemented with conjugated linoleic acid (CLA) or linoleic acid (Ctrl). Supplementation of CLA or control fat preparation lasted for the first $9 \mathrm{wk}$ in milk. Values are least squares means \pm SEM; $\mathrm{n}=10$ per group. Significant main effects $(P<0.05$ or lower $)$ were revealed for diet (milk fat content and fat yield), time (milk yield, milk fat content, and fat yield), and diet $\times$ time interaction (milk yield) during supplementation and for diet (milk fat content), time (milk fat content and fat yield), and diet $\times$ time interaction (milk fat content and fat yield) during depletion.
PEPCKc and G6Pase tended to be lower $(P<0.1$ and $P<0.15$ ) in CLA-fed than in Ctrl-fed cows (Table 7 ).

\section{DISCUSSION}

\section{Effects of CLA on Milk Performance and Body Condition}

Extent of milk fat reduction during CLA supplementation corresponds to previous studies (Baumgard et al., 2000; Selberg et al., 2004; Castañeda-Gutiérrez et al., 2005). Milk fat concentration became significantly lower in CLA- than in Ctrl-fed cows after wk 2 of lactation, although CLA feeding started 2 wk before parturition. The delay in milk fat depression is in line with previous studies (Bernal-Santos et al., 2003; Castañeda-Gutiérrez et al., 2005; Odens et al., 2007) and is probably induced by peripartal processes, because during established lactation milk fat depression occurs shortly after commencing CLA supplementation (Giesy et al., 2002, Perfield et al., 2002). Milk fat contained the trans-10,cis-12 CLA isomer at wk 3 of lactation and, therefore, it was transferred to the mammary gland during early lactation. As suggested, the trans-10,cis-12 CLA isomer predominantly inhibits de novo FA synthesis in the mammary gland (Bauman and Griinari, 2003; Peterson et al., 2003; Odens et al., 2007). However, milk fat during early lactation may contain more long-chain FA derived from body fat mobilization rather than newly synthesized FA. We observed a lower proportion of short- and medium-chain FA in milk fat, which seems to support the notion that CLA-related depression of milk fat is due to reduced de novo FA synthesis. However, according to Bauman et al. (2008), milk fat depression induced by trans-10,cis-12 CLA inhibits both de novo synthesis and milk fat synthesis from preformed FA. Thus, reasons for the delay of milk fat depression by trans-10, cis-12 CLA with the onset of lactation are not clear. Milk protein content decreased with time, but was not affected by CLA feeding in the current study, which is in agreement with previous findings (Castañeda-Gutiérrez et al., 2005; Pappritz et al., 2011).

Cows fed CLA in the current study showed higher milk production after 5 wk postpartum. The delay in CLA-related stimulation of milk production was probably associated with the described delay in milk fat depression during early lactation, as discussed above, but the distinctiveness of the milk production increment in CLA-fed cows was surprising. Although no differences in plasma NEFA and BHBA concentrations could be observed, the calculated energy balance during CLA supplementation was more negative in CLA than in Ctrl-fed cows due to slightly lower DMI in 
Table 4. Effects of conjugated linoleic acid (CLA) feeding on fatty acid composition in milk samples from wk 3 and wk 9 of lactation ${ }^{1,2}$

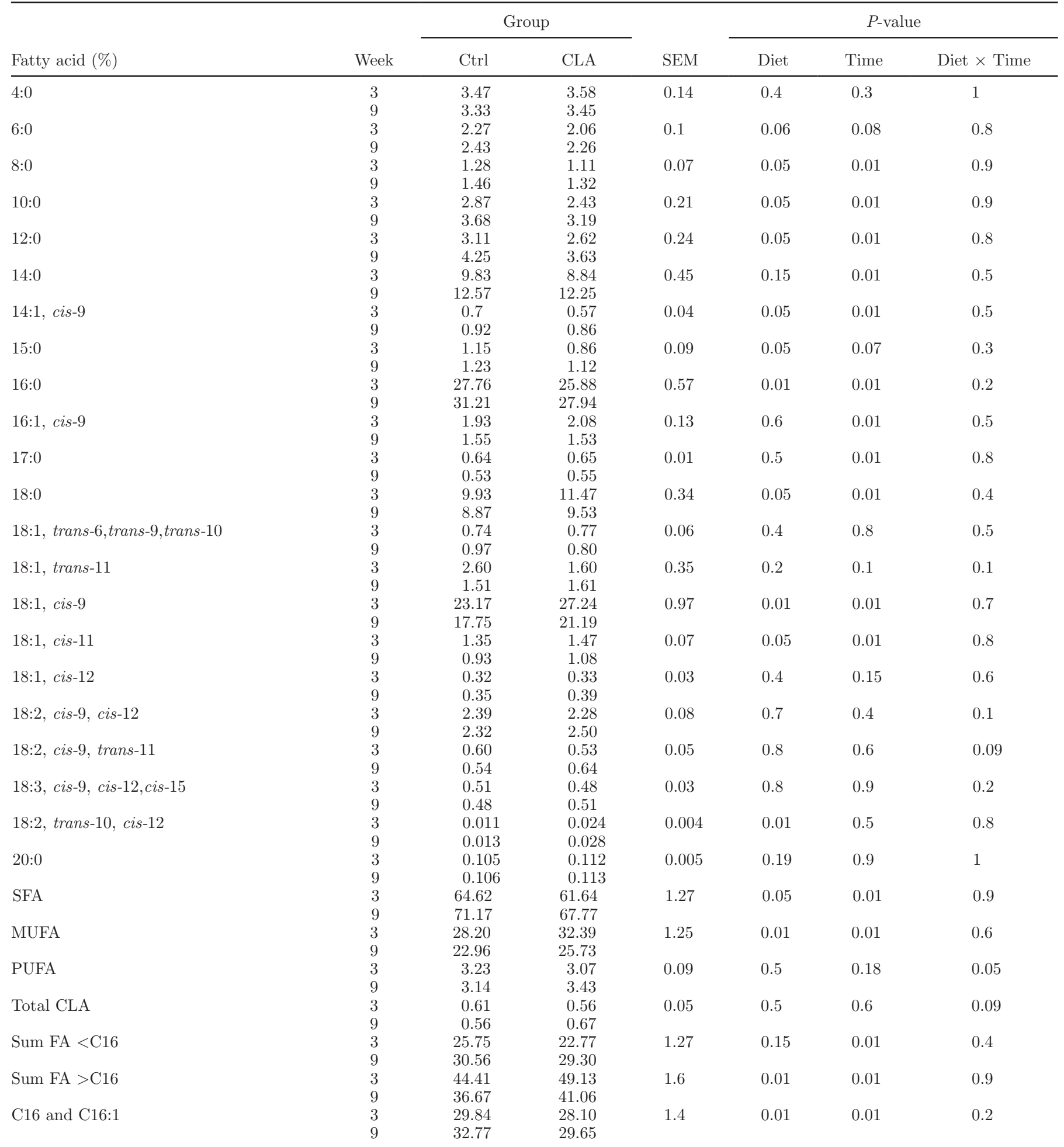

${ }^{1}$ Samples were collected in wk 3 and wk 9 of lactation from cows supplemented with CLA and control fat (Ctrl), fed from 2 wk before parturition up to wk 9 of lactation.

${ }^{2}$ Values are least squares means and pooled SEM, $\mathrm{n}=10$ per group. 


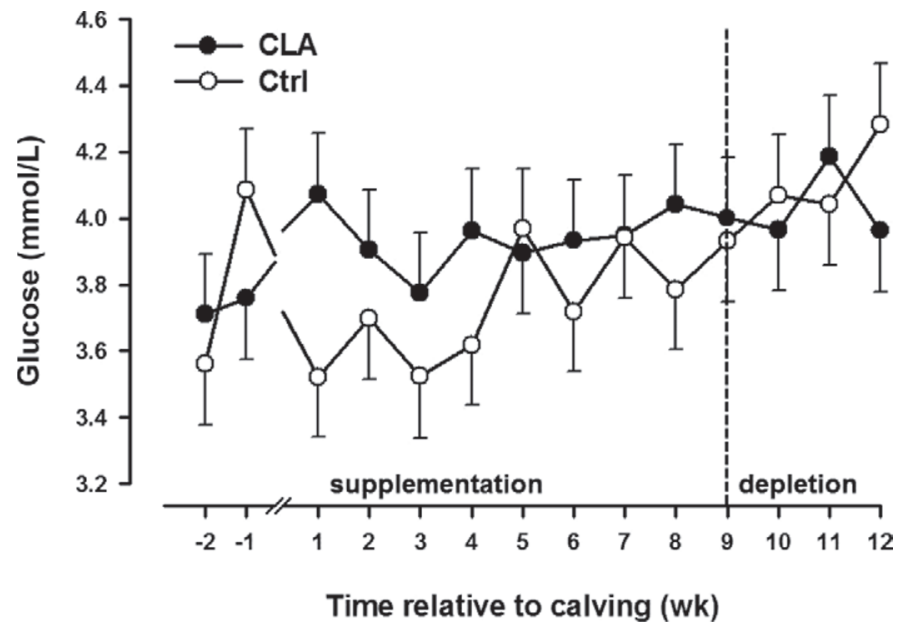

Figure 2. Plasma glucose concentrations during supplementation and depletion time in conjugated linoleic acid (CLA) and control (Ctrl). Values are least squares means $\pm \mathrm{SEM} ; \mathrm{n}=10$ per group. Significant main effects $(P<0.01)$ were revealed for diet $\times$ time interaction during supplementation.

CLA-fed cows but comparable ECM yield. Reports on responses of DMI and calculated energy balance to CLA feeding are not consistent. Inhibitory (Moallem et al., 2010; Pappritz et al., 2011; von Soosten et al., 2011), stimulating (Shingfield et al., 2004), as well as no effects (Perfield et al., 2002; Bernal-Santos et al., 2003; Castañeda-Gutiérrez et al., 2005; Odens et al., 2007; von Soosten et al., 2011) on DMI were reported. In addition, CLA feeding in dairy cows was shown to alleviate (Shingfield et al., 2004; Odens et al., 2007), as well as exacerbate (Pappritz et al., 2011), postpartum negative energy balance, whereas others reported no effect (Bernal-Santos et al., 2003; Selberg et al., 2004; Castañeda-Gutiérrez et al., 2005; Moallem et al., 2010). This variation in DMI and calculated energy balance due to CLA feeding might depend on study design (e.g., the amounts of trans-10,cis-12 CLA isomer fed or stage of lactation when CLA feeding was initiated) but suggests that CLA supplementation may not necessarily result in an improved energy status in dairy cows during early lactation. However, calculations of energy balance do not consider CLA effects on body composition, presumably via reduced fat mobilization or on inflammatory status that may result in changes of maintenance requirements and an improved tissue energy level after CLA supplementation (Shingfield et al., 2004; Trevisi et al., 2008; von Soosten et al., 2012).

Table 5. Effect of conjugated linoleic acid (CLA) supplementation from 2 wk before parturition to wk 9 of lactation on blood plasma concentration of metabolites and hormones in cows ${ }^{1,2}$,

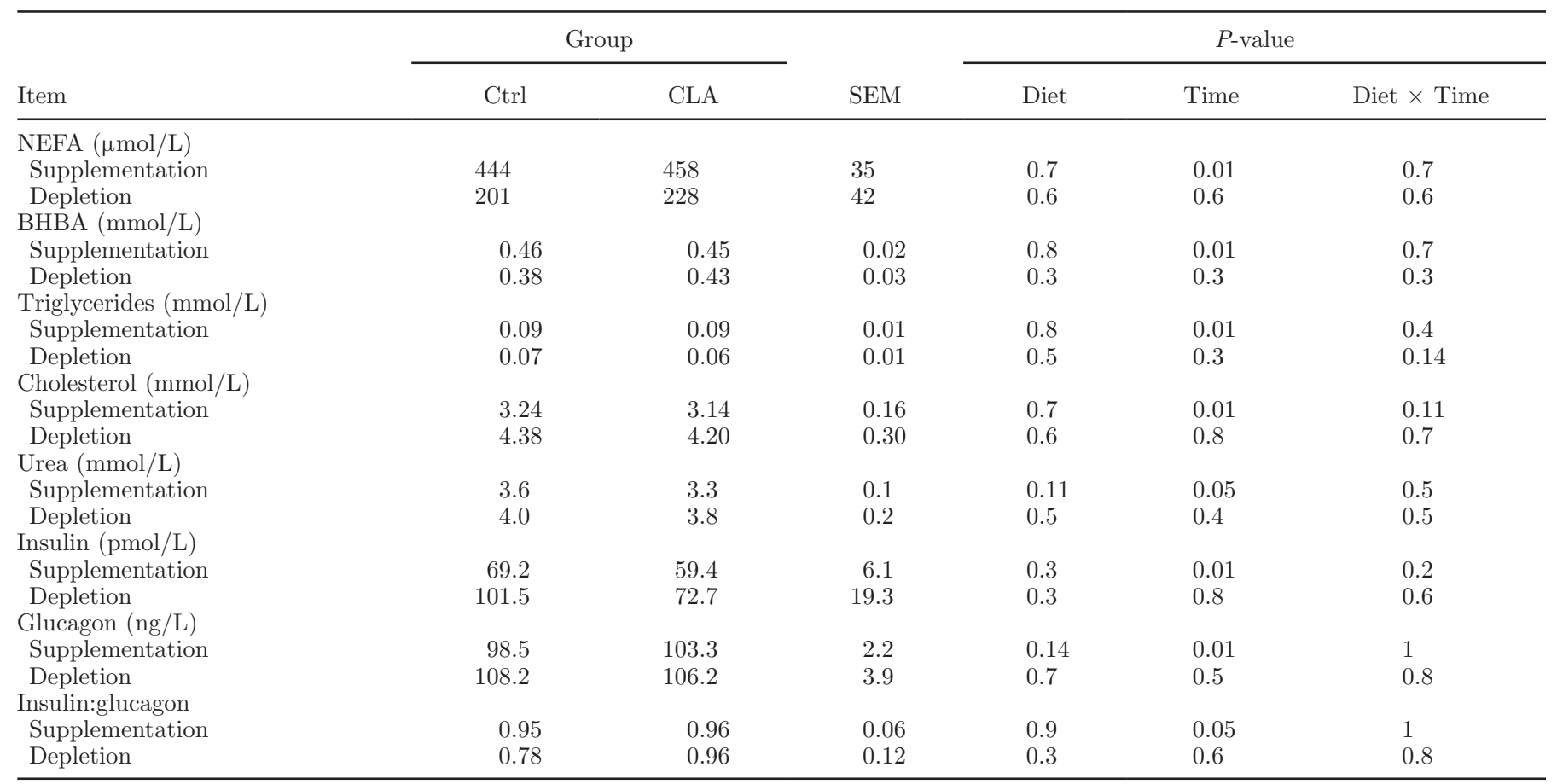

${ }^{1}$ Samples were collected from wk 2 before parturition to wk 9 of lactation (supplementation period) and from wk 10 to wk 12 of lactation (depletion period) from cows supplemented with CLA and control (Ctrl) fat, fed from 2 wk before parturition up to wk 9 of lactation.

${ }^{2}$ Values are least squares means and pooled $\mathrm{SEM}, \mathrm{n}=10$ per group.

${ }^{3}$ Time courses of parameters are presented as figures in a Supplementary File, available online at http://www.journalofdairyscience.org/. 
Table 6. Effect of conjugated linoleic acid (CLA) supplementation from 2 wk before parturition to wk 9 of lactation on endogenous glucose production (eGP) and glucose oxidation (GOx) as well as plasma concentrations of glucose and insulin during glucose tolerance test (GTT) in wk 3 and wk 9 of lactation ${ }^{1,2}$

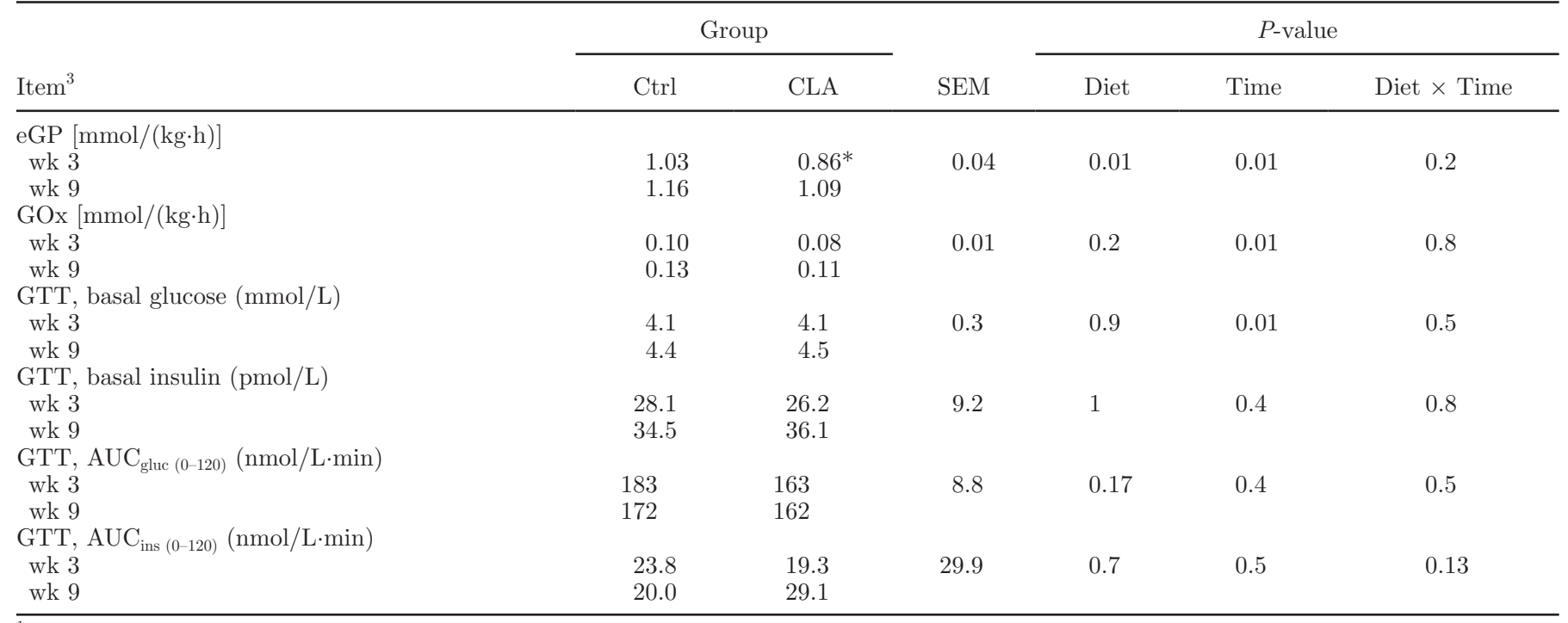

${ }^{1}$ Samples were collected in wk 3 and wk 9 of lactation from cows supplemented with CLA and control (Ctrl) fat, fed from 2 wk before parturition up to wk 9 of lactation.

${ }^{2}$ Values are least squares means and pooled SEM, $\mathrm{n}=10$ per group.

${ }^{3} \mathrm{eGP}=$ endogenous glucose production; GOx $=$ glucose oxidation; $\mathrm{GTT}=$ glucose tolerance test; $\mathrm{AUC}_{\text {gluc }(0-120)}$ was calculated to estimate glucose disposal and $\mathrm{AUC}_{\text {ins }(0-120)}$ to estimate insulin response after intravenous injection of $1 \mathrm{~g} / \mathrm{kg}^{0.75}$ of glucose.

*Different from control $(P<0.05)$.

Table 7. Effect of conjugated linoleic acid (CLA) supplement from 2 wk before parturition to wk 9 of lactation on fat and glycogen concentrations and mRNA concentrations of liver enzymes relative to that of $\mathrm{GAPDH}^{1,2}$

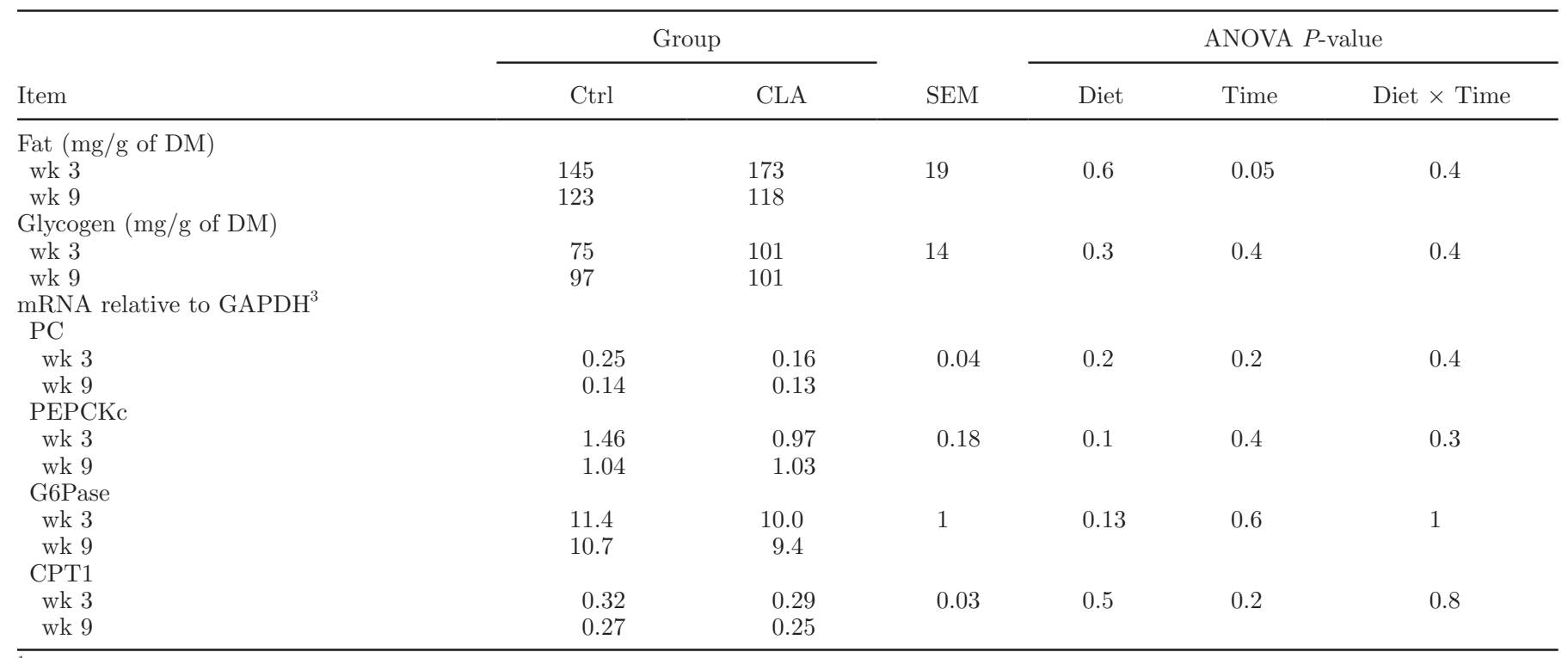

${ }^{1}$ Samples were collected in wk 3 and wk 9 of lactation from cows supplemented with CLA and control fat (Ctrl), fed from 2 wk before parturition up to wk 9 of lactation.

${ }^{2}$ Values are least squares means and pooled SEM, $\mathrm{n}=10$ per group.

${ }^{3} \mathrm{PC}=$ pyruvate carboxylase; PEPCKc $=$ cytosolic phosphoenolpyruvate carboxykinase; G6Pase = glucose-6-phosphatase; CPT1 = carnitine palmitoyl-transferase 1 . 


\section{CLA Effects on Glucose Metabolism}

The rate of eGP measured in Ctrl-fed cows in wk 3 of lactation was in line with data published earlier (Knowlton et al., 1998), and eGP corresponded well to the level of milk production (Aschenbach et al., 2010). Endogenous glucose production increased with ongoing lactation in both groups, supporting the concept of increased eGP with increased DMI in ruminants (Bell and Bauman, 1997; Brockman, 2005; Aschenbach et al., 2010). The amount of available glucose is important to achieve the full genetic potential for milk production, because lactose is the major osmoregulator for mammary uptake of water (Linzell, 1972; Danfaer, 1994; Rigout et al., 2002).

Although plasma glucose concentrations were higher during early lactation in CLA-fed than Ctrl-fed cows, eGP in wk 3 of lactation was lower in CLA-fed cows. Probably, decreased eGP and elevated plasma glucose concentrations reflect the reduced glucose need (e.g., for milk fat synthesis) but could additionally result from a more efficient use of metabolizable energy in CLA-fed cows (Voigt et al., 2005; von Soosten et al., 2012). Ruminants mainly use acetate and butyrate as substrates for FA synthesis, but glucose is needed for milk fat synthesis in ruminants as well to provide NADPH for de novo FA synthesis and glycerol (Palmquist and Jenkins, 1980; Grummer and Carroll, 1991; Bauman and Griinari, 2003; Voigt et al., 2005). On the other hand, lactose output increased with CLA feeding, as more glucose was available for lactose synthesis, despite eGP reduction in CLA-fed cows. We assume a higher lactose synthesis due to higher glucose availability because of less glucose use for milk fat synthesis in CLA-fed cows and therefore a greater milk yield in CLA-fed cows (Linzell, 1972; Danfaer, 1994; Rigout et al., 2002). In contrast to long-chain FA in rumen-protected fat, the trans-10,cis-12 CLA isomer inhibits milk fat synthesis in the mammary gland, resulting in a reduced milk fat content; whereas rumen-protected long-chain FA feeding did not inhibit milk fat content, but reduced de novo FA synthesis and increased milk fat synthesis from long-chain FA (Grummer and Carroll, 1991; Bauman et al., 2008).

In addition, recent findings on tissue mobilization and protein accretion in CLA-fed cows point to a more efficient use of metabolizable energy due to CLA supplementation during early lactation. Indeed, when we calculated the overall glucose sparing in the mammary gland we determined about $122 \mathrm{~g}$ of glucose/d due to less glycerol and FA synthesis, but an additional use of glucose for lactose production in CLA-fed cows of about $77 \mathrm{~g}$ of glucose/d, resulting in an overall glucose- sparing effect in the mammary gland of about $45 \mathrm{~g}$ of glucose/d (for a cow with BW of $600 \mathrm{~kg}$ ). Because the overall eGP reduction in CLA-fed cows compared with Ctrl-fed cows was $311 \mathrm{~g}$ of glucose/d (600 kg BW during $9 \mathrm{wk}$ of lactation), more glucose sparing probably occurred in tissues other than the mammary gland. The additional glucose sparing might result from the improved feed efficiency in CLA-fed cows (von Soosten et al., 2012), which may lead to reduced whole-body glucose use. Therefore, the reduced eGP in CLA-fed cows might be a consequence of reduced fat synthesis in the mammary gland, but also a result of a more efficient use of metabolizable energy.

The decreased glucose demand may have caused higher plasma glucose concentrations in our study and, at the same time, decreased the need for eGP to retain glucose homeostasis. This is in contrast to feeding of rumen-protected fat, where plasma glucose concentrations decreased, but eGP was unchanged (Hammon et al., 2008). The slightly lower DMI in CLA-fed cows probably contributed to the decreased eGP observed in our study, likely caused by lower propionate availability in CLA-fed cows (Aschenbach et al., 2010). The decreasing effect of CLA feeding on eGP was less distinct in wk 9 than in wk 3 of lactation, suggesting differences in eGP regulation with ongoing lactation that were probably related to increased gluconeogenesis from propionate due to increased DMI in both groups (Bell and Bauman, 1997; Brockman, 2005; Aschenbach et al., 2010).

With the onset of lactation, GOx decreases dramatically in dairy cows, because cows reduce GOx in muscle and fat tissue during early lactation to provide sufficient glucose for milk synthesis (Danfaer, 1994; Bell and Bauman, 1997). Furthermore, GOx is inversely correlated to milk production (Hammon et al., 2010). The GOx obtained in the present study supports previous measurements (Hammon et al., 2008), and the increasing rate of GOx with lactation is in line with increasing eGP and glucose availability (Danfaer, 1994; Bell and Bauman, 1997). Glucose oxidation was numerically lower in CLA- than Ctrl-fed cows, which seems to support the hypothesis of lower glucose use in CLA-fed cows. The reasons why we did not see a more distinct reduction of GOx in CLA-fed cows are not known. Because GOx is low during early lactation, a more distinct reduction by CLA feeding may occur in mid-lactation cows. In addition, although we have not seen different glycogen concentrations in liver between CLA- and Ctrl-fed cows, glucose was probably used for glycogen synthesis in muscle to refill glycogen depots that were degraded with onset of lactation as we have previously demonstrated (Kuhla et al., 2011). 
Elevated plasma glucose concentrations, but reduced eGP in CLA-fed cows might not be a consequence of impaired insulin action. Based on basal plasma insulin concentrations and GTT results, an insulin resistance due to CLA feeding could be excluded in our study, which supports previous findings (Baumgard et al., 2002; Bauman et al., 2008). Insulin resistance is known from rodents fed diets high in CLA, but those doses were substantially higher than that fed to dairy cows in the present study (Winzell et al., 2006). In addition, insulin response is less sensitive in the liver compared with other tissues, such as skeletal muscle and fat (Vernon, 2005), and insulin might be not responsible for the decreased eGP in CLA-fed cows. This assumption is further supported by the lack of difference in plasma glucagon and the glucagon to insulin ratio between groups. Therefore, reduced eGP might be a result of autoregulation (Danfaer, 1994; Brockman, 2005), although the regulation of eGP by glucokinase activity may be less pronounced in ruminants (Moore et al., 1998; Tappy et al., 2000).

The mRNA concentrations of PEPCKc and G6Pase tended to be reduced in CLA-fed cows, which supports the overall finding of reduced eGP. In a previous study, CLA supplementation did not affect hepatic mRNA of PC and PEPCKc in dairy cows during early lactation (Selberg et al., 2004), but rumen-protected fat supplementation resulted in decreased G6Pase mRNA concentrations in liver (Lohrenz et al., 2010). As supplementation of trans-10,cis-12 CLA, as well as rumen-protected fat, results in a glucose-sparing effect, hepatic gene expression of G6Pase might be a key factor in regulating eGP by reducing glucose delivery to the circulation. Interestingly, CLA treatment decreased gluconeogenesis in porcine hepatocytes, possibly due to increased hepatic insulin sensitivity (Conde-Aguilera et al., 2012). However, it is not clear whether this is also the case in bovine hepatocytes, and, as discussed above, CLA may have not changed insulin sensitivity in our study. Conversely, CLA feeding did not affect CPT1 mRNA concentrations in liver. The CPT1 mRNA codes for a key enzyme-initiating hepatic FA oxidation. Therefore, hepatic FA oxidation was probably not affected by CLA feeding in line with the lack of difference in liver fat concentrations.

\section{CONCLUSIONS}

In conclusion, our data show reduced eGP in dairy cows supplemented with CLA containing the trans10,cis-12 isomer. Diminished eGP was associated with decreased milk fat yield, but partially elevated milk production and a more negative energy balance during early lactation. Although CLA supplementation did not result in improved energy status, more glucose was excreted in the milk, but less glucose was used in the mammary gland and probably also in other tissues, indicating a glucose-sparing effect in CLA-fed cows. The decreased glucose use was counterbalanced by reduced eGP to retain glucose homeostasis and enable a more efficient milk production.

\section{ACKNOWLEDGMENTS}

We thank U. Lüdtke, C. Reiko, A.-K. Möller, I. Brüning, M. Fengler, and A. Fischer (Nutritional Physiology, FBN Dummerstorf, Germany), and Yolande Zbinden (Veterinary Physiology, University of Bern, Switzerland) for analytical assistance. Additional thanks are due to M. Becker (Nutritional Physiology, FBN Dummerstorf) for experimental support, as well as B. Stabenow and the Animal Experimental Unit of the FBN for excellent technical assistance. The Rinderzuchtverband Mecklenburg-Vorpommern is acknowledged for logistic support with selection of cows. The study was supported by BASF, Ludwigshafen, Germany.

\section{REFERENCES}

Aschenbach, J. R., N. B. Kristensen, S. S. Donkin, H. M. Hammon, and G. B. Penner. 2010. Gluconeogenesis in dairy cows: The secret of making sweet milk from sour dough. IUBMB Life 62:869-877.

Bauman, D. E. 2000. Regulation of nutrient partitioning during lactation: Homeostasis and homeorhesis revisited. Pages 311-328 in Ruminant Physiology: Digestion, Metabolism, Growth and Reproduction. P. B. Cronje, ed. CABI International, Wallingford, UK.

Bauman, D. E., and J. M. Griinari. 2003. Nutritional regulation of milk fat synthesis. Annu. Rev. Nutr. 23:203-227.

Bauman, D. E., J. W. Perfield, K. J. Harvatine, and L. H. Baumgard. 2008. Regulation of fat synthesis by conjugated linoleic acid: Lactation and the ruminant model. J. Nutr. 138:403-409.

Baumgard, L. H., B. A. Corl, D. A. Dwyer, and D. E. Bauman. 2002. Effects of conjugated linoleic acids (CLA) on tissue response to homeostatic signals and plasma variables associated with lipid metabolism in lactating dairy cows. J. Anim. Sci. 80:1285-1293.

Baumgard, L. H., B. A. Corl, D. A. Dwyer, A. Saebo, and D. E. Bauman. 2000. Identification of the conjugated linoleic acid isomer that inhibits milk fat synthesis. Am. J. Physiol. Regul. Integr. Comp. Physiol. 278:R179-R184.

Bell, A. W., and D. E. Bauman. 1997. Adaptations of glucose metabolism during pregnancy and lactation. J. Mammary Gland Biol. Neoplasia 2:265-278.

Bernal-Santos, G., J. W. Perfield, D. M. Barbano, D. E. Bauman, and T. R. Overton. 2003. Production responses of dairy cows to dietary supplementation with conjugated linoleic acid (CLA) during the transition period and early lactation. J. Dairy Sci. 86:3218-3228.

Brockman, R. P. 2005. Glucose and short-chain fatty acid metabolism. Pages 291-310 in Quantitative Aspects of Ruminant Digestion and Metabolism. J. Dijkstra, J. M. Forbes, and J. France, ed. CAB International, Wallingford, UK.

Castañeda-Gutiérrez, E., T. R. Overton, W. R. Butler, and D. E. Bauman. 2005. Dietary supplements of two doses of calcium salts 
of conjugated linoleic acid during the transition period and early lactation. J. Dairy Sci. 88:1078-1089.

Conde-Aguilera, J. A., M. Lachica, R. Nieto, and I. Fernández-Fígares. 2012. Metabolic regulation of fatty acid esterification and effects of conjugated linoleic acid on glucose homeostasis in pig hepatocytes. Animal 6:254-261.

Danfaer, A. 1994. Nutrient metabolism and utilization in the liver. Livest. Prod. Sci. 39:115-127.

Drackley, J. K., T. R. Overton, and G. N. Douglas. 2001. Adaptations of glucose and long-chain fatty acid metabolism in liver of dairy cows during the periparturient period. J. Dairy Sci. 84(E. Suppl.):E100-E112.

Duske, K., H. M. Hammon, A. K. Langhof, O. Bellmann, B. Losand, K. Nürnberg, G. Nürnberg, H. Sauerwein, H. M. Seyfert, and C. C. Metges. 2009. Metabolism and lactation performance in dairy cows fed a diet containing rumen-protected fat during the last twelve weeks of gestation. J. Dairy Sci. 92:1670-1684.

Eastridge, M. L. 2006. Major advances in applied dairy cattle nutrition. J. Dairy Sci. 89:1311-1323.

German Society of Nutrition Physiology. 2001. Ausschuss für Bedarfsnormen der Gesellschaft für Ernährungsphysiologie, No. 8. Empfehlungen zur Energie- und Nährstoffversorgung der Milchkühe und Aufzuchtrinder (Recommended energy and nutrient supply for dairy cows and growing cattle). DLG-Verlag Frankfurt a. Main, Germany.

Giesy, J. G., M. A. McGuire, B. Shafii, and T. W. Hanson. 2002. Effect of dose of calcium salts of conjugated linoleic acid (CLA) on percentage and fatty acid content of milk fat in midlactation Holstein cows. J. Dairy Sci. 85:2023-2029.

Grummer, R. R., and D. J. Carroll. 1991. Effects of dietary fat on metabolic disorders and reproductive performance of dairy cattle. J. Anim. Sci. 69:3838-3852.

Hammon, H. M., and J. W. Blum. 1998. Metabolic and endocrine traits of neonatal calves are influenced by feeding colostrum for different durations or only milk replacer. J. Nutr. 128:624-632.

Hammon, H. M., C. C. Metges, P. Junghans, F. Becker, O. Bellmann, F. Schneider, G. Nurnberg, P. Dubreuil, and H. Lapierre. 2008. Metabolic changes and net portal flux in dairy cows fed a ration containing rumen-protected fat as compared to a control diet. J. Dairy Sci. 91:208-217.

Hammon, H. M., C. C. Metges, A. Schulz, P. Junghans, J. Steinhoff, F. Schneider, R. Pfuhl, R. M. Bruckmaier, R. Weikard, and C. Kühn. 2010. Differences in milk production, glucose metabolism, and carcass composition of 2 Charolais $\times$ Holstein $\mathrm{F}_{2}$ families derived from reciprocal paternal and maternal grandsire crosses. J. Dairy Sci. 93:3007-3018.

Hammon, H. M., G. Stürmer, F. Schneider, A. Tuchscherer, H. Blum, T. Engelhard, A. Genzel, R. Staufenbiel, and W. Kanitz. 2009. Performance and metabolic and endocrine changes with emphasis on glucose metabolism in high-yielding dairy cows with high and low fat content in liver after calving. J. Dairy Sci. 92:1554-1566.

Knowlton, K. F., T. E. Dawson, B. P. Glenn, G. B. Huntington, and R. A. Erdman. 1998. Glucose metabolism and milk yield of cows infused abomasally or ruminally with starch. J. Dairy Sci. $81: 3248-3258$.

Kokkonen, T., J. Taponen, T. Anttila, L. Syrjala-Qvist, C. Delavaud, Y. Chilliard, M. Tuori, and A. T. Tesfa. 2005. Effect of body fatness and glucogenic supplement on lipid and protein mobilization and plasma leptin in dairy cows. J. Dairy Sci. 88:1127-1141.

Kuhla, B., G. Nürnberg, D. Albrecht, S. Görs, H. M. Hammon, and C. C. Metges. 2011. Involvement of skeletal muscle protein, glycogen, and fat metabolism in the adaptation on early lactation of dairy cows. J. Proteome Res. 10:4252-4262.

Kuhla, S., M. Klein, U. Renne, W. Jentsch, P. E. Rudolph, and W. B. Souffrant. 2004. Carbon and nitrogen content based estimation of the fat content of animal carcasses in various species. Arch. Anim. Nutr. 58:37-46.

Linzell, J. L. 1972. Mechanism of secretion of the aqueous phase of milk. J. Dairy Sci. 55:1316-1322.

Lohrenz, A. K., K. Duske, F. Schneider, K. Nürnberg, B. Losand, H. M. Seyfert, C. C. Metges, and H. M. Hammon. 2010. Milk perfor- mance and glucose metabolism in dairy cows fed rumen-protected fat during mid lactation. J. Dairy Sci. 93:5867-5876.

Moallem, U., H. Lehrer, M. Zachut, L. Livshitz, and S. Yacoby. 2010. Production performance and pattern of milk fat depression of high-yielding dairy cows supplemented with encapsulated conjugated linoleic acid. Animal 4:641-652.

Moore, M. C., C. C. Connolly, and A. D. Cherrington. 1998. Autoregulation of hepatic glucose production. Eur. J. Endocrinol. 138:240-248.

Naumann, C., and R. Bassler. 2004. Die chemische Untersuchung von Futtermitteln. 3rd ed. VDLUFA-Verlag, Darmstadt, Germany.

Odens, L. J., R. Burgos, M. Innocenti, M. J. VanBaale, and L. H. Baumgard. 2007. Effects of varying doses of supplemental conjugated linoleic acid on production and energetic variables during the transition period. J. Dairy Sci. 90:293-305.

Palmquist, D. L., and T. C. Jenkins. 1980. Fat in lactation rations: Review . J. Dairy Sci. 63:1-14

Pappritz, J., U. Meyer, R. Kramer, E. M. Weber, G. Jahreis, J. Rehage, G. Flachowsky, and S. Danicke. 2011. Effects of long-term supplementation of dairy cow diets with rumen-protected conjugated linoleic acids (CLA) on performance, metabolic parameters and fatty acid profile in milk fat. Arch. Anim. Nutr. 65:89-107.

Perfield, J. W., G. Bernal-Santos, T. R. Overton, and D. E. Bauman. 2002. Effects of dietary supplementation of rumen-protected conjugated linoleic acid in dairy cows during established lactation. J. Dairy Sci. 85:2609-2617.

Peterson, D. G., E. A. Matitashvili, and D. E. Bauman. 2003. Diet-induced milk fat depression in dairy cows results in increased trans-10, cis-12 CLA in milk fat and coordinate suppression of mRNA abundance for mammary enzymes involved in milk fat synthesis. J. Nutr. 133:3098-3102.

Pfaffl, M. W. 2001. A new mathematical model for relative quantification in real-time RT-PCR. Nucleic Acids Res. 29:e45.

Rigout, S., S. Lemosquet, J. E. van Eys, J. W. Blum, and H. Rulquin. 2002. Duodenal glucose increases glucose fluxes and lactose synthesis in grass silage-fed dairy cows. J. Dairy Sci. 85:595-606.

Selberg, K. T., A. C. Lowe, C. R. Staples, N. D. Luchini, and L. Badinga. 2004. Production and metabolic responses of periparturient holstein cows to Dietary conjugated linoleic acid and trans-octadecenoic acids. J. Dairy Sci. 87:158-168.

Shingfield, K. J., D. E. Beever, C. K. Reynolds, S. K. Gulati, D. J. Humphries, B. Lupoli, G. Hervas, and J. M. Griinari. 2004. Effect of rumen protected conjugated linoleic acid on energy metabolism of dairy cows during early to mid-lactation. J. Dairy Sci. 87(Suppl. 1):307. (Abstr.)

Sigl, T., G. Schlamberger, H. Kienberger, S. Wiedemann, H. H. Meyer, and M. Kaske. 2010. Rumen-protected conjugated linoleic acid supplementation to dairy cows in late pregnancy and early lactation: Effects on milk composition, milk yield, blood metabolites and gene expression in liver. Acta Vet. Scand. 52:16.

Steinhoff-Wagner, J., S. Görs, P. Junghans, R. M. Bruckmaier, E. Kanitz, C. C. Metges, and H. M. Hammon. 2011. Intestinal glucose absorption but not endogenous glucose production differs between colostrum- and formula-fed neonatal calves. J. Nutr. 141:48-55.

Tappy, L., E. Jequier, and P. Schneiter. 2000. Autoregulation of glucose production. News Physiol. Sci. 15:198-202.

Trevisi, E., A. Ferrari, F. Piccioli-Capelliand, and G. Bertoni. 2008. Energy balance indexes and blood changes of dairy cows supplemented with rumen protected CLA in late pregnancy and early lactation. J. Dairy Sci. 91(Suppl. 1):77. (Abstr.)

van Dorland, H. A., S. Richter, I. Morel, M. G. Doherr, N. Castro, and R. M. Bruckmaier. 2009. Variation in hepatic regulation of metabolism during the dry period and in early lactation in dairy cows. J. Dairy Sci. 92:1924-1940.

Vernon, R. G. 2005. Metabolic regulation. Pages 443-468 in Quantitative Aspects of Ruminant Digestion and Metabolism. J. Dijkstra, J. M. Forbes, and J. France, ed. CAB International, Wallingford, UK

Voigt, J., K. Gaafar, W. Kanitz, D. Precht, F. Becker, F. Schneider, M. Spitschak, U. Schonhusen. P. Junghans, J. R. Aschenbach, and G. Gäbel. 2005. Utilization of glucose and long-chain fatty acids 
in lactating dairy cows fed a fat-enriched diet. Dtsch. Tierarztl. Wochenschr. 112:423-425. (In German)

von Soosten, D., U. Meyer, M. Piechotta, G. Flachowsky, and S. Dänicke. 2012. Effect of conjugated linoleic acid supplementation on body composition, body fat mobilization, protein accretion, and energy utilization in early lactation dairy cows. J. Dairy Sci. 95:1222-1239.

von Soosten, D., U. Meyer, E. M. Weber, J. Rehage, G. Flachowsky, and S. Dänicke. 2011. Effect of trans-10,cis-12 conjugated linoleic acid on performance, adipose depot weights, and liver weight in early-lactation dairy cows. J. Dairy Sci. 94:2859-2870.

Winzell, M. S., G. Pacini, and B. Ahren. 2006. Insulin secretion after dietary supplementation with conjugated linoleic acids and n-3 polyunsaturated fatty acids in normal and insulin-resistant mice. Am. J. Physiol. Endocrinol. Metab. 290:E347-E354. 